UNIVERSITY OF GOTHENBURG

SCHOOL OF BUSINESS, ECONOMICS AND LAW

WORKING PAPERS IN ECONOMICS

No 534

\title{
Trade and Resources: Welfare Effects of the \\ Lake Victoria Fisheries Boom
}

Håkan Eggert, Mads Greaker and Asmerom Kidane

May 2012

ISSN 1403-2473 (print)

ISSN 1403-2465 (online) 


\title{
Trade and Resources: Welfare Effects of the Lake Victoria Fisheries Boom
}

\author{
Håkan Eggert, Mads Greaker and
}

Asmerom Kidane ${ }^{1}$

Keywords: International fish trade, Lake Victoria, Nile perch, Poverty reduction, Tanzania

JEL Classification: F18, Q2, Q22, Q56

\footnotetext{
${ }^{1}$ University of Gothenburg, P.O. Box 640, SE 40530 Göteborg, Sweden; tel: +46-31-773 4175; fax: +46-31-773 1326; e-mail: Hakan.Eggert@economics.gu.se , University of Gothenburg, and University of Dar es Salaam.
} 


\begin{abstract}
In this paper we examine the welfare implications of the Tanzanian fisheries boom following from the increase in quantities and prices of the Lake Victoria Nile perch export during 19932008. We use the theoretical model by Brander and Taylor (1997) that we try to test empirically. We have a micro level perspective using data from a 1993 World Bank household survey and our own study from 2008, both containing data from about 520 households in the two regions Mwanza and Mara by the lake. Our results indicate that average income has increased in both rural and urban areas. For the poorest part of the population, rural areas experienced only modestly and non-significantly reductions in the fraction below basic needs, while urban areas had a substantial reduction. However, growth was modest and inequality seems to have increased during the period. Concerning human capital measured as education for the household head we found substantial improvements in educational level and a simple regression model confirmed the significant impact of education on household income. We also found that households on average are better off when situated close to the lake.
\end{abstract}

\title{
Acknowledgement
}

We gratefully acknowledge support from the research program, Environment and Trade in a World of Interdependence (Entwined), funded by the Foundation for Strategic Environmental Research (Mistra), Sweden. Financial support from Sida (Swedish International Development and Cooperation Agency) to the Environment for Development, Tanzania, and from Formas through the program Human Cooperation to manage natural resources (Commons) is also gratefully acknowledged. We thank our colleagues in the research program at ENTWINED for comments. Thanks to Andrea Mannberg for excellent field work, and to Dr Razack Lokina, University of Dar es Salaam, for coordinating the data collection. 
"The export of fish from Lake Victoria to the rich parts of the world has developed into a social catastrophe for the local population...Most of the fish are transformed into a high quality product and exported to Europe, the US and Japan. At the same time the inhabitants by the lake suffer from undernourishment.” (Eirik G. Jansen, interviewed in Apollon, 2006)

Fish is the main source of animal protein for 20 percent of the world's population. More than 40 percent of the global fish production is traded internationally. The net exports of fishery commodities by developing countries, i.e., deducting their imports from the total value of their exports, have increased to $\$ 24.6$ billion in 2006 . That figure exceeds the sum of total net exports of other important agricultural commodities for developing countries, such as coffee, rubber, cocoa, and meat (FAO, 2008). Liberalization of trade is generally advocated as a positive factor in improving the standards of living for a country's population. Countries can combine their resources in an optimal way to produce goods and services, and trade offers an opportunity to achieve higher levels of consumption for all involved parties, compared to autarky. Hence, trade liberalization has been promoted with the idea that developing countries will be better off if rich countries lower their tariffs and allow imports to increase. Similarly, foreign direct investment or joint venture projects in poor countries offer opportunities for technology diffusion and increased welfare (Bhagwati 2001).However, with several distortions coexisting in an economy (poorly defined property rights and trade barriers), removing one of them (trade barriers) may lead to ambiguous welfare effects (Lipsey and Lancaster, 1956). Chichilnisky (1994) basically revived this seminal result and showed for renewable resources that when property rights are completely absent, trade can be detrimental to stocks, and reduce the welfare of resource-exporting 
countries. Brander and Taylor (1997) hold that a small tradable renewable resource sector would only have modest impact on aggregate economic performance, but show that if the renewable resource sector is large enough trade liberalization combined with open access may imply welfare reductions for a country. In their model, trade liberalization of renewable resources lead to labor shifting from manufacturing to harvesting of the natural resource. When harvest of the resource increases, the stock is reduced until a new open access equilibrium is reached with lower catches. Since manufacturing returns to the same level as before the opening of trade, welfare for the country stabilizes at a lower level. Brander and Taylor (1997) assume full employment, free access to capital needed for harvesting, constant returns to scale in all sectors ${ }^{\mathrm{i}}$ and no regulation and/or social control of the renewable resource. Clearly, some or all of these assumptions may not hold in a real world economy.

In this paper we try to assess the welfare implications of the Tanzanian fisheries boom following from the increase in quantities and prices of Nile perch export primarily to Europe since the early 1990s. Lake Victoria fisheries are poorly managed and may be characterized as open-access. Thus, according to Brander and Taylor (1997) we may find that trade liberalization has led to declining harvests and, all other things equal, a potential decline in welfare levels. On the other hand, imperfect capital markets and informal rules may work as an entry barrier to the fishery, which would postpone the movement to the new open access equilibrium. In the transition phase welfare may temporarily increase, at least for those having access to the fishery. Furthermore, there is no reason to doubt that the Lake Victoria fisheries have provided Tanzania with high export revenues. According to the "trickle down" theory this should improve livelihood also for the poor (see e.g. Aghion and Bolton, 1997). However, the anti-fish trade literature distrusts the "trickle down" effect, and contends that trade in food such as fish 
primarily leads to increasing fish prices while too little of the growing income ends up with the poor in order to offset the increasing prices, leading to declining welfare levels for the poor. Hence, we look at the welfare levels of the residents in the Lake Victoria regions.

Béné et al (2010) reviews the literature on economic growth and trade in fish between developed and developing countries. The pro-trade strand of literature argues that fish trade can act as an engine of growth, among others, by providing an important source of hard cash flow. The other strand of literature, the anti-fish trade, contends that trade in fish negatively affects food security, local economies and incomes of the poor. The dramatic increases in many of the important world food commodity prices 2007-2008 led to a reinforced concern about whether trade liberalization may lead to reduced food security. Particular worry is given to the poorest part of the world, i.e. Sub-Saharan Africa, where there is an ongoing debate about whether liberalizing fish trade has pro-poor effect or leads to negative effects on local populations' food security and welfare development (see also Geheb et al., 2008; Abila, 2003; Jansen, 1997).

Many fisheries in developing countries are poorly managed and often close to openaccess. However, if trade liberalization leads to an increased exploitation of a relatively virgin stock, there may be economic rents through the transitional stage when effort and landings increase. Potentially, these rents can be re-invested in other parts of the economy. Much of the discussion between the pro- and anti-fish trade proponents seem to be centered around whether these rents "trickle down" through the economy such that the poor also benefits.

Béné et al. (2010) carry out a macro level study of the effect of liberalizing fish trade on economic growth and look at all sub Saharan countries. In their econometric study, they do not find any significant relationship between trade and negative impact on food security, nor a positive pro-poor outcome, but point at the potential of investigating these issues on a more 
micro oriented level. In this study our focus is on the micro level perspective. Our point of departure is a 1993 World Bank household survey of Tanzania including the lake side regions (HRDS, 1996). ${ }^{\mathrm{ii}}$ We use the data collected for the two regions Mwanza and Mara and compare them with our own household survey data, which were collected for a random sample in the same regions during October-November in 2008 using a similar questionnaire as in the 1993 survey. Hence, we can quantitatively estimate changes over time and assess the welfare effects both in terms of level and distributional impact.

\section{THE ARTISANAL LAKE VICTORIA FISHERIES}

Lake Victoria is the largest tropical lake in the world (68,000 square kilometers), with its waters shared by three countries, Tanzania, 49\%, Uganda, 45\%, and Kenya 6\%. Approximately onethird of the population or about 30 million people are supported by the lake basin in Kenya, Tanzania and Uganda (LVFO, 1999). Commercial fishing has been carried out for a long time but the economic importance of fishing has increased dramatically since the late 1980s. In the 1950s and 1960s the non-indigenous species Nile perch (Lates niloticus) and Nile tilapia (Oreochromis niloticus) were introduced to compensate for depleting commercial fisheries by converting low-value small fish to more easily caught higher-value species. This had minor impact for many years, but during the 1980s landed quantities was radically amplified and even more so in terms of value. Fishers called Nile perch the mkombozi, saviour in Kiswahili, (Reynolds, Gréboval and Mannini, 1992). Later on, a growing share of the Nile perch catch has been exported, primarily to Europe. The rapid growth of Nile perch came at the expense of a severe reduction of the available number of species. Lake Victoria was known for more than 600 
endemic species of haplochromis cichlids. About $40 \%$ of these species disappeared and the Nile perch seems to have been a key contributor to this mass extinction with contributions from environmental changes (Balirwa et al, 2003). Today the fisheries mainly consist of three commercially important species; Nile perch, the sardine like dagaa (Rastrineobola argentea) and the Nile tilapia. In 2006 Nile perch, dagaa and Nile tilapia contributed 24\%, 54\%, and 7\%, respectively of total Lake Victoria landings (LVFO, 2012).

Fishers in Lake Victoria use open wood vessels, which sometimes have outboard motors, but most commonly are operated by sail or paddle. The total crew ranges from two to six persons. Owners of the boats are commonly involved in beach activities, e.g. selling the catch, and in some cases are on-board their vessel as captain or ordinary crew. There are two dominant types of fishing units on the Lake: Nile perch/Tilapia gill nets and Dagaa nets. Nets are placed in the late afternoon and retrieved in the morning. Because of the concern with theft, fishers often stay out with the net, sleeping in their boats. Dagaa is fished at night when the moon is dark using pressure lamps to attract them, which limits fishing to 15 days a month. Dagaa is usually caught with gillnets, but illegal short purse seines and mosquito nets are also used. In addition, some fishers use longlines, usually baited with dagaa, haplochromis or other small fish, which enables them to catch larger Nile perch specimen than what could be caught by gillnets. Tilapias are sometimes caught with hooks and lines but in most case small-mesh gill nets.

In principle, entry into the Lake Victoria fisheries is open to anyone with enough capital and the necessary skills. However, getting the capital and acquiring the skills may take some time. There is no catch limit, thus participating fishers can catch as much as they can, given the stock level and their vessels capacity. Fishing requires an annual license fee that approximately equals the gross revenues from two days of fishing, which merely function as a friction to free entry (Eggert and Lokina, 2010). 


\section{OPEN-ACCESS FISHERIES AND TRADE: POTENTIAL WELFARE EFFECTS}

Chichilnisky (1994) brought the attention to the potential problem of combining trade liberalization with open-access natural resources. Brander and Taylor (1997) provided formal proofs that trade and open access may lead to welfare reductions. Since then a rich literature has developed (For recent surveys see e.g. Bulte and Barbier, 2005; Fischer, 2010). Many of the extensions increase the level of complexity, and given that Brander and Taylor (1997) is complex enough, we use their model and focus on examining the potential empirical links between their model and the real world example of Tanzanian Nile perch export from the Lake Victoria fisheries. With respect to the effects of opening up to trade, their model and their assumptions yield the following results:

First, an autarchy country starting to trade an open-access natural resource may experience negative welfare effects from trade. Second, any resource-abundant country with a too large labor force to accommodate specialization in natural resource production, will by necessity obtain lower welfare in the new equilibrium. Although the transition stage is beneficial for the exporting country, a small enough discount rate implies that trade leads to an overall reduction of welfare, irrespective of the relative price of the natural resource good.

Brander and Taylor (1997) assume full employment, free access to capital needed for harvesting, constant returns to scale in all sectors and no regulation and/or social control of the renewable resource. Labor is either allocated to the resource sector or to manufacturing. Resource-abundance is defined as the ratio between the growth rate of the natural resource and the size of the labor force, i.e., a country with a fast growing species may have an autarchy price 
lower than the world market price and at the same time a too large labor force to accommodate all of it in the resource sector.

When landings of Nile perch took off during the mid-1980s, companies in all three countries established fillet processing industries by the lake. The export nowadays contributes with a substantial share of the foreign currency earnings in each country. Tanzanian Nile perch export amounted to \$ 150 million in 2008, which was about 5\% of total Tanzanian exports (NBS, 2011). Roughly 70\% of the catch is landed in Mwanza and Mara, which in 2008 had a total population of about 5 millions, i.e. about $12 \%$ of Tanzania's population. Hence, the economic importance of the fishery to these two regions is non- negligible.

Despite signs that the stock has been reduced (LVFO, 2012), landings have been maintained at an annual level of about 300,000 tons since the early 1990s. Focusing on Tanzania, we see a decline from about 120,000 tons in the 1990 s to a, so far, stable level of 100,000 tons for most of the years during the new millennium (see figure 1). 
Figure 1. Nile perch landings in Lake Victoria 1977-2008

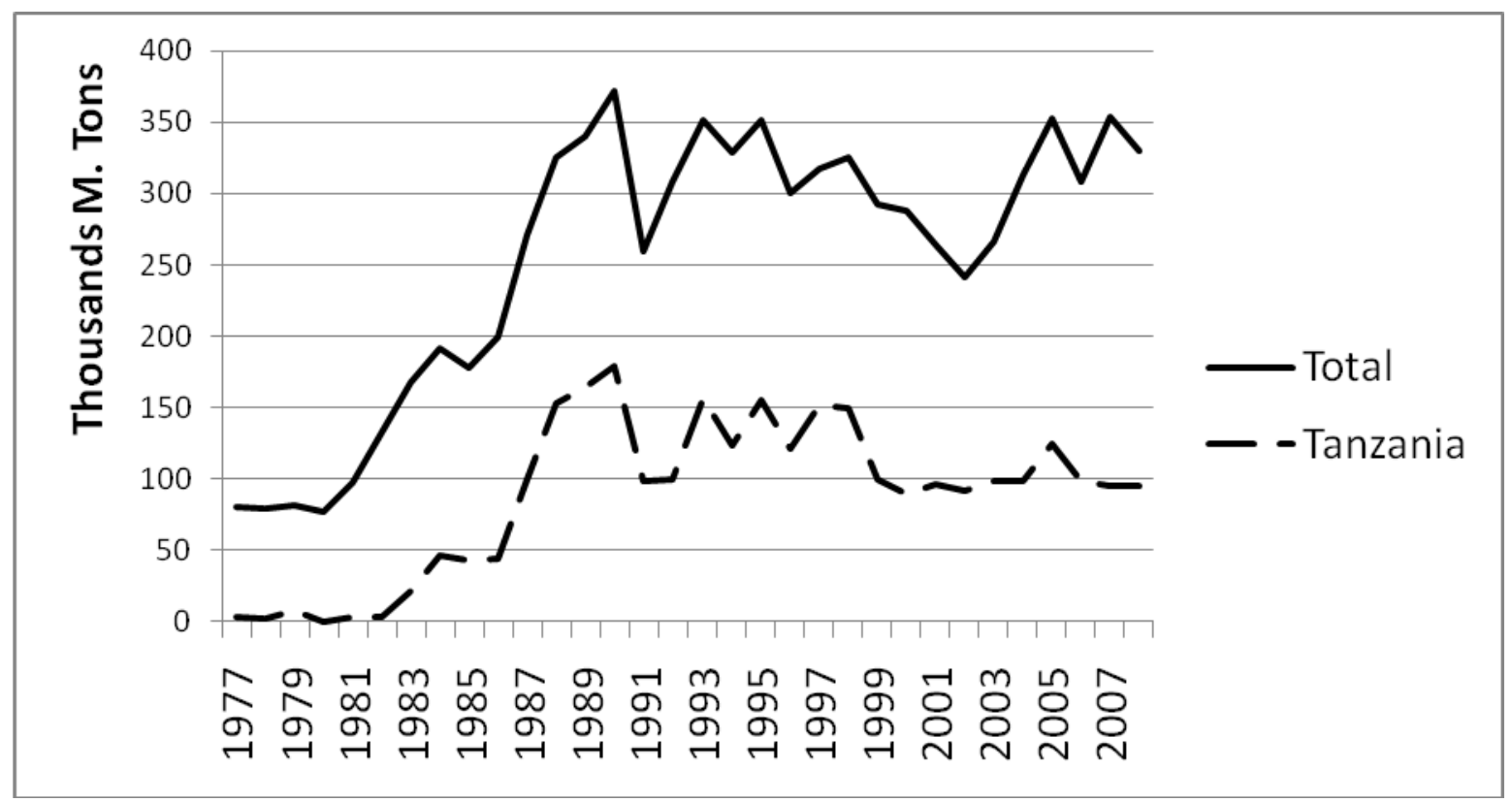

(FAO FishStat, 2010)

In the frictionless model of Brander and Taylor (1997), trade liberalization and a higher world market price than the autarchy price rapidly shifts the workforce to fishing. Harvest exceeds the net surplus production and the stock is reduced, and for a large enough labor force the new steady state equilibrium will be at a stock level below maximum sustainable yield, and at such a low level that equilibrium harvest is below the autarchy level. Figure 1 gives the impression that landings have stabilized, which for Tanzania means a level about 100,000 tons, and that potentially a new open-access equilibrium has been reached, i.e., landings are equal to net surplus growth and total value of landings are equal to total costs of fishing.

However, when we look at development of fishing effort it is hard to find support for equilibria either from an economic or from a biological perspective. From 1985 effort, measured as number of boats fishing in the lake, has increased dramatically. Until 1989 catch per unit effort (CPUE), here measured as annual catch per boat, increased but then started to decline, 
and in 2006 cpue was only 40\% of the average during the peak years 1989-90, as shown in Figure 2. ${ }^{\text {iii }}$ The number of fishermen has more than tripled from 1985 to 2006. Personal communication with Tanzanian fishers on site indicate that the average crew size from 1985 to 2005 was reduced from an average of five to three, which give a rough estimate of 60,000 fishers in 1985 that had increased to about 200,000 in 2006, of which $40 \%$ or approximately 80,000 are Tanzanian fishers (LVFO, 2012). The World Fact Book (CIA, 2012) estimated the whole labor force of Tanzania to be almost $56 \%$ of the total population in 2010 . If we assume that $70 \%$ of the Tanzanian fishermen live in Mwanza and Mara a crude estimate indicate that 56,000 fishermen constitute $2 \%$ of the labor force in the two regions.

Figure 2. Annual catch per boat (effort) and number of boats in Lake Victoria 1975-2006

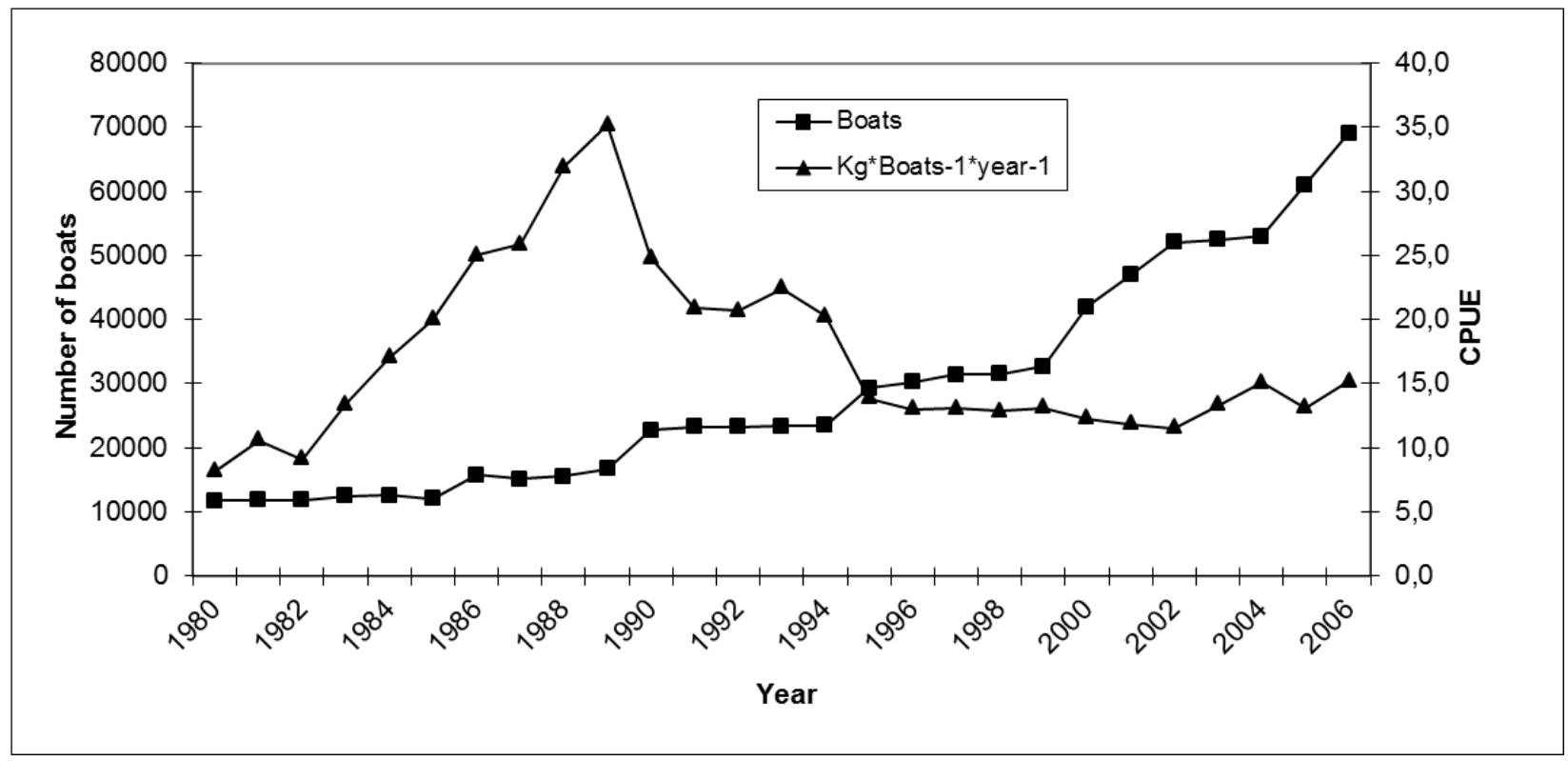

(Authors’ calculation using data from LVFO, 2004; Warui, 2007 and Geheb et al, 2008))

The two model assumptions of full employment and free access to capital needed for harvesting are most likely severely violated for the Tanzanian Lake Victoria fisheries. CIA fact book (2012) states unemployment figures not available for Uganda and Tanzania, but 
provide an estimate of $40 \%$ unemployment in Kenya, which probably is a decent proxy also for the even poorer Tanzania. Hence, an excess amount of outside unemployed workers would like to become fishermen despite declining income among existing fishermen. On the other hand, high interest rates in the informal credit markets combined with the license cost slow down the entry. Concerning the biological development of the stock, the reduction in cpue indicates a severe reduction of the Nile perch stock, and a number of biological studies have predicted a collapse if the increase in exploitation pressure is not halted (Pitcher and Bundy, 1995; Mkumbo et al., 2002; Balirwa et al., 2003;; Njiru et al., 2007). ${ }^{\text {iv }}$

Given the limited share of fishermen compared to the total labor force in Mwanza and Mara, despite almost 30 years of rapid increase, it is likely that the Nile perch fishery export only have had modest impact on aggregate economic performance. The strong, second result of Brander and Taylor (1997) seems unlikely as real world conditions seriously violate the assumptions of the model. Concerning the first result, we find some support as fishing effort has increased greatly and fishermen income likely have declined considerably since the peak years around 1990. Whether overall welfare has increased in Mwanza and Mara is uncertain and the same applies for the distributional impact. We address these two issues in the remainder of this article.

4 MEASURING WELFARE CHANGES IN MWANZA AND MARA 1993-2008

Our aim with this study was to measure the welfare changes among the Tanzanian population by the lake from early 1990s until 2008. To be able to test this in a robust statistical way we would ideally have panel household data collected at least in the beginning and at the end of the period. No such data existed to our knowledge. A second alternative would have been to collect 
household data and ask respondents to also provide recall data of conditions 15 years earlier. However, such a long time frame would add substantial uncertainty which is hard to control for. Deaton (2001) discusses problems with too long recall periods and refers to studies where modest changes in recall period had dramatic impact on the final results. As an alternative we found the World Bank data (HRDS, 1996). In 1993 the Population and Human Resources Division of the East Africa Department of World Bank carried out a household survey for Tanzania. That study included 516 households from the regions Mwanza and Mara by the lake (another 200 was also sampled in Kagera, the third lakeside region, but it was excluded due to limited funds for our survey). The 1993 data only had a handful of households directly relying on fisheries, and given our aim of comparing the two surveys and the limited amount of household that we could survey, we used a random sampling strategy. Potentially, for a larger sample, a stratified approach of sampling fishers' households and non-fishers' household could be useful in an attempt to more explicitly isolate the impact of the fishing industry, which may be considered for future studies.

In order to minimize the deviations due to differences in context and methods, we used the questionnaire from the 1993 survey to design a questionnaire where the recall periods were equally long for each type of expenditure, i.e., annually, monthly and weekly. In line with recommendations (Deaton, 2001) income was measured as total expenditures where respondents were asked to state the value in Tanzanian shillings (Tsh) of consumed quantities, which were either bought, produced, received in kind, given as gift, loan or compensation. The sampling procedure in 1993 used a two-stage cluster sampling approach, which implies that the village weights should be used in the final analysis. For the 2008 sample we applied proportionate probability sampling meaning that no further adjustment is needed in the final analysis of the data (for details on the methods see Deaton, 1997). 
In addition we wanted to know whether development by the lake had been similar or different to the rest of the country. In order to try to carry out such comparisons we also used the existing household budget surveys (HBS) carried out by the National Bureau of Statistics (NBS) in Tanzania in 1991/92, 2000/01 and 2007 (NBS, 2012).

The 1993 and 2008 household surveys

Table 1 shows the distribution of household sizes in rural and urban areas for the two regions at the two points in time, where household is defined as the persons who normally live in the dwelling and eat meals together. We note a minor increase of the fraction of large households, five or more in a household, during the period but at the same time the average household size has slightly decreased in both rural and urban areas.

Table 1. Distribution of household sizes in the Mwanza and Mara regions in the 1993 and 2008 surveys

\begin{tabular}{lllll}
\hline & Rural & & Urban \\
Household Size & 1993 & 2008 & 1993 & 2008 \\
\hline 1 & 0.3 & 0.8 & 2.0 & 2.3 \\
2 & 3.4 & 2.7 & 5.1 & 3.8 \\
$3-4$ & 20.3 & 14.3 & 27.8 & 22.6 \\
$5-6$ & 28.0 & 24.0 & 26.7 & 30.3 \\
$7-8$ & 22.2 & 27.0 & 16.1 & 27.2 \\
$9+$ & 25.7 & 31.0 & 22.4 & 13.8 \\
Mean Hh Size & 7.1 & 6.9 & & \\
Sampled Hhs & 261 & 258 & 6.2 & 5.9 \\
\hline
\end{tabular}

A crude but simple measure of the level of human capital is the education of the household head. Dercon and Krishnan (1998) found for Ethiopian farmers that increased educational level of the household head implied lower poverty levels, reduced fluctuations in poverty over season and 
increased the chances of getting better off over time. In 1964, by the time of independence, Tanzania had an extremely poorly educated population. Sarris and Tinios (1995) found increases in educational level from 1976 to 1991 where for instance the fraction of those with no education went from 54/39\% (rural/urban) to $29 / 16 \%$ for the whole country. Our data confirm a continued improvement in terms of education, which is reported in table 2. The fraction of the population with No education is down from 21.9/14.5\% in 1993 to 5.8/3.4\% in 2008 and Some or complete secondary has increase from 5.4/16.9\% in 1993 to $6.2 / 22.6 \%$ in 2008 .

Table 2. Education levels of heads of hh in Mwanza and Mara 1993 and 2008

\begin{tabular}{lllll}
\hline & Rural & \multicolumn{3}{c}{ Urban } \\
& 1993 & 2008 & 1993 & 2008 \\
\hline No education & 21.9 & 5.8 & 14.5 & 3.4 \\
Some or complete primary & 69.6 & 81.1 & 61.2 & 62.8 \\
Some or complete secondary & 5.4 & 6.2 & 16.9 & 22.6 \\
Post-secondary & 0.3 & 0.0 & 2.0 & 5.0 \\
Adult education \& Other & 1.5 & 4.2 & 1.2 & 4.2 \\
Nonstated or missing & 1.1 & 1.9 & 4.3 & 1.5 \\
\hline
\end{tabular}

In order to adjust for differences in household sizes we use the calorie based equivalence scales developed by WHO (Dercon and Krishnan, 1998) where individuals are divided into females and males and into 13 different age classes and given weights in the range of $0.33-1.14$. Finally, adjusting for inflation is another requisite for comparison. We used the IFS data base CPI (IMF, 2010), which is available both on monthly and annual basis for our period of interest. 
Comparing welfare levels in 1993 and in 2008

Both for 1993 and 2008 some village leaders provided assessments of prices on staple food like rice, corn, meat, fish etc. We noted large price variations within each sample year, but also confirmed the real food price increases for 2007-2008. In addition, we noted that real price increases for meat and fish were substantial, resulting in some substitution for other sources of protein by the households. In the 2008 survey respondents were asked about which type of fish they would primarily eat today, ten years ago and twenty years ago. In 1988, Tilapia and Nile perch were the main fish type for almost all households, where presumably poorer households would buy the cheapest fish protein at the time, fish frames of Nile perch. From 1988 to 2006 the landings of the small anchovy like fish Dagaa increased from less than 100,000 tons to almost 600,000 tons (Geheb et al., 2008), and likely provided the cheapest source of fish protein as either fresh or dried in 2008. At the same time real prices of Tilapia and Nile perch increased, which is reflected by the priorities made in 2008. The increases in prices of particularly Nile perch is also confirmed explicitly by the respondents in 2008 of which almost $90 \%$ hold that the impact of the fish factories and the fish export is primarily negative, and of those more than $80 \%$ held increasing fish prices and reduced availability as the major reason for the negative impact.

Table 3. Main fish species in Mara and Mwanza household meals in 2008, 1998, and 1988

\begin{tabular}{lccccccc}
\hline Main species (\%) & Tilapia & Dagaa & $\begin{array}{l}\text { Nile perch } \\
\text { whole fish }\end{array}$ & $\begin{array}{c}- \text { Nile perch } \\
\text { fish frames }\end{array}$ & Other fish & Obs \\
\hline Today & 21 & 46 & 21 & 11 & 2 & 519 \\
10 years ago & 41 & 14 & 33 & 11 & 1 & 516 \\
20 years ago & 49 & 2 & 32 & 16 & 1 & 512 \\
\hline
\end{tabular}


In Table 4 we report the weighted mean income, measured as total expenditures per adult equivalent scaled, in 2008 Tsh. Mean rural average income per adult equivalent in 1993 expressed as 2008 Tsh was 740,000, or roughly USD 620 with the average exchange rate for USD/Tsh in 2008*. The corresponding figure for 2008 was Tsh 770,000, a small but significant increase. Similar development was recorded for average urban income, from Tsh 1,040,000 to Tsh 1,160,000, a small, but significant increase.

Table 4. Comparing welfare levels in Mwanza and Mara

\begin{tabular}{llrrr}
\hline & & $\mathbf{1 9 9 3}$ & $\mathbf{2 0 0 8}$ & \multicolumn{1}{c}{ t-stat } \\
\hline $\begin{array}{l}\text { Weighted mean } \\
\text { Exp per adult equiv in 2008 Tsh }\end{array}$ & Rural & 740,000 & 770,000 & -5.1 \\
& Urban & $1,040,000$ & $1,160,000$ & -12.2 \\
$\begin{array}{l}\text { Average food share of total consumption } \\
\text { per hh }\end{array}$ & & $75.9 \%$ & $65.6 \%$ & -15.3 \\
*USD 1 = Tsh 1200, 2008 & & & \\
\end{tabular}

We also find that on average there was a substantial improvement with respect to the food share of total consumption over the period. The average food share of total consumption was $75.9 \%$ in 1993 while the corresponding figure for 2008 was $65.6 \%$.

The average annual growth in weighted mean expenditure for the households over the period is modest with $0.3 \%$ and $0.7 \%$ per year for rural and urban areas, respectively. The corresponding figures based on the HBSs for Tanzania in 1991/92, 2000/01 and 2007 are 1.5\% from 1991/92 to 2001, and 1.9\% from 2001 to 2007. Hence, if a comparison between different surveys is meaningful (we discuss this particular issue later on), these figures indicate that average growth rates in mean expenditure from 1991 to 2008 were lower in Mwanza and Mara than for the country on average, and splitting the latter figures into rural and urban does not alter the result. 
In order to say something about the poorer fraction of the population we need additional measures. The HBS provides figures of 'basic needs' poverty lines expressed in Tsh for 91/ 92 and 2007, respectively ${ }^{2}$. We used these figures and inflated them by the IFS CPI (IMF, 2012) to get the corresponding 1993- and 2008-lines. We could then calculate the fractions below the poverty lines for our samples.

Table 5. Comparing basic need levels in Mwanza and Mara

\begin{tabular}{llrrr}
\hline & & $\mathbf{1 9 9 3}$ & $\mathbf{2 0 0 8}$ & t-stat \\
\hline Basic Needs based on & Rural areas & $15.0 \%$ & $14.0 \%$ & 1.2 \\
HBS 1991/2007 & Urban areas & $17.9 \%$ & $8.1 \%$ & 17.7 \\
\hline
\end{tabular}

In table 5, we report the results of how large fraction of our samples that earned less than the 'basic needs' poverty line. We see that in rural areas there is a reduction in poverty but it is small and not statistically significant. However, for the urban areas of Mwanza and Mara we find a substantial and statistically significant reduction in the fraction of poor below the basic needs level from 17.9 to 8.1 per cent. In table 6, we provide comparative figures for Tanzania computed by the HBS:

Table 6. Comparing basic need levels in the rest of Tanzania

\begin{tabular}{llrr}
\hline & & $\mathbf{1 9 9 1 / 9 2}$ & $\mathbf{2 0 0 7}$ \\
\hline \multirow{2}{*}{ Fraction below basic needs levels } & Dar es Salaam & $28.1 \%$ & $16.4 \%$ \\
(based on deflated levels from HBS) & Rural areas & $40.8 \%$ & $37.6 \%$ \\
& Other Urban areas & $28.7 \%$ & $24.1 \%$ \\
& Mainland Tanzania & $38.6 \%$ & $33.6 \%$ \\
\hline
\end{tabular}

Notably, our 1993 and 2008 results are substantially lower than what is reported for the HBSs from corresponding years. In addition, urbanpoverty in Mwanza and Mara was substantially

${ }^{2}$. In the 2000/01 survey the HBS calculated a 'basic needs' poverty line based on the minimum adult calorific requirement with a food consumption pattern typical of the poorest 50 percent of the population and then adjusted for non-food share of expenditures of the poorest 25 percent of the population. To get adjusted 'basic need' poverty lines for the 91/92 and 2007 surveys, they adjusted for price changes by using a Fisher price index. 
more reduced compared to urbanpoverty in Tanzania, excluding Dar es Salaam. Still, the results reinforce the impression of the difficulty of comparing various household budget surveys. Eele et al. (2000) reported the problems of comparing seven different household surveys carried out in Tanzania during 1983 and 1999, where methodologies, definitions and populations covered differed. The overall impression from comparing our 2008 data and the 1993 World Bank data with the HBS surveys in Tanzania is that rural areas in Mara and Mwanza have had a development at pair with rural areas in the rest of Tanzania during 1993 to 2008, while other urban areas in Mwanza and Mara have had a substantially better development compared to the average other urbanareas in Tanzania. The level of improvement seems to be even better or at least at pair with the development pace of the metropolitan area of the biggest city in the country, Dar es Salaam. ${ }^{\mathrm{v}}$

Sarris and Tinios (1995) showed how sensitive comparisons are regarding particularly adjustments for inflation when assessing welfare development in Tanzania. According to the official consumer price index of Tanzania CPI (IMF, 2012) the average annual price increases were $12,4 \%$ from 1993 to 2008. However, if we look at the basic-need levels in Tsh from the HBS, thesehave increased by $8.7 \%$ on average in the period from 1993 to 2008. Of course, this could indicate that other prices have increased more than food prices. On the other hand, the official consumer price index of Tanzania may overstate the inflation which then would explain our low growth figures for mean expenditure reported in Table 4.

To get additional information of inequality of income, we also calculated the Gini coefficients for Mara and Mwanza in 1993 and 2008. The results indicate that inequality of income has increased from 0.356 in 1993 to 0.500 in 2008. Moreover, the change is significant since we calculate the standard deviation of the Gini to be slightly less than 0.03 . 
The HBSs for Tanzania found a stable Gini of about 0.35 for Tanzania as well as for urban and for rural areas from 1991/92 to 2007. This figure may be too low. Using all 5000 observations for Tanzania from the 1993 World bank study gives a Gini of 0.45, i.e. substantially higher than the 1991/92 HBS result of 0.34. Again this illustrates the problem of comparing figures from different studies.

\section{An Alternative method of comparing welfare}

Another approach to measure welfare development, sometimes referred to as poverty mapping, based on combining data from household surveys and census data has been developed in recent years (Hentschel et al., 2000; Minot, 2000; Elbers et al., 2003). The point of departure is to estimate the relationship between poverty and household characteristics, where the latter are collected at various points in time. Based on the assumption that the explanatory variable coefficients are constant over the time period studied, health surveys where data on the household characteristics are collected can then be transformed into welfare estimates. This approach do not imply any improvement in analysing our data per se as we have income data collected for both occasions, but we can explore whether our data actually have significant socio economic variables explaining income. We ran ordinary least squares (OLS) regressions on the two data sets. For the 2008 data we also have distance measures from the sample sites to lake Victoria, which we use to construct two alternative dummy variables indicating whether the sampled households are either within 2 or $10 \mathrm{~km}$ from the beach of the lake. In Table 7 we report the summary statistics of the variables used in the regression. The two samples are fairly similar with an average equivalent adult scaled household size of fully five, a mean household head age of 44 years, about $15 \%$ of heads are female, and about $50 \%$ have farm work as main income. Heads having fishing as main income are less than a handful in each sample. Paid employee 
includes government, parastatal and private, which is a group that has been significantly reduced when comparing the samples, a development off set by the increase in self-employed. For the 2008 sample we note that $64 \%$ of the households are situated $10 \mathrm{~km}$ or less from the lake.

Table 7. Summary statistics of 1993 and 2008 sample used for income regression.

\begin{tabular}{|c|c|c|c|c|}
\hline & \multicolumn{2}{|c|}{2008} & \multicolumn{2}{|c|}{1993} \\
\hline & Mean & $\begin{array}{l}\text { Std } \\
\text { Dev }\end{array}$ & Mean & $\begin{array}{l}\text { Std } \\
\text { Dev }\end{array}$ \\
\hline household_count_adult_equivalent & 5.22 & 2.07 & 5.35 & 3.01 \\
\hline household_count_adult_equivalent_squared & 31.5 & 21.9 & 37.6 & 54.1 \\
\hline head_age & 44.3 & 14.2 & 43.6 & 13.2 \\
\hline head_female & 0.16 & & 0.15 & \\
\hline head_activity_farmwork & 0.46 & & 0.51 & \\
\hline head_activity_looking_for_work & 0 & & 0.002 & \\
\hline head_activity_fishing & 0.006 & & 0.004 & \\
\hline head_activity_paid_employee & 0.12 & & 0.26 & \\
\hline head_activity_self_employed & 0.30 & & 0.17 & \\
\hline head_activity_other & 0.07 & & 0.04 & \\
\hline head_activity_missing & 0.02 & & 0.02 & \\
\hline head_education_none & 0.05 & & 0.18 & \\
\hline head_education_primary & 0.72 & & 0.65 & \\
\hline head_education_secondary & 0.14 & & 0.11 & \\
\hline head_education_postsecondary & 0.03 & & 0.01 & \\
\hline head_education_adult & 0 & & 0.01 & \\
\hline head_education_other & 0.04 & & 0 & \\
\hline head_education_missing & 0.02 & & 0.03 & \\
\hline village_lake_10km & 0.64 & & & \\
\hline village_lake_2km & 0.31 & & & \\
\hline
\end{tabular}

When comparing the income figures and socio economic variable it is not obvious which way the causality goes, i.e., if there is significant relationship it may be that a change in income has led to changes in education and work or it may be the other way around; the change in income is a result of changes in work and education. Ideally, we should have an instrumental variable to avoid these potential problems, but we lack any suitable instrumental variable in order to use e.g. 
a two stage least square approach (see e.g. Greene, 1997). In Table 8 we report the results of the regressions where the dependent variable is log of expenditures per adult equivalent. Larger households are poorer than smaller but the negative effect of a larger household is decreasing in size, while neither age nor gender for household head has an impact on income per adult equivalent. In 1993, the handful household heads working as fishers made substantially more money than the reference alternative, farm work, but such difference does not occur for the 2008 sample. Employees working of government, parastatal or private companies made significantly more than those doing farm work in 1993 but such differences had vanished in 2008, potentially explaining the reduction of paid employees. Similarly, self-employed made substantially more than those doing farm work in 1993, but the significant difference remains in 2008, indicating why the fraction of self-employed has increased so much during the period. When we look at educational level for the 1993 data, we find that those with some or completed secondary education as well as those with post-secondary education have significantly higher income than the reference group, i.e. those with some or completed primary education. The 14 heads with missing educational status also made more. For the 2008 sample, the picture is even clearer, income increases monotonically with education from the group of heads with none education to those with post-secondary education, which is in line with results of Minot (2007). We also note that for the 2008 data there are clear indications that households closer to the lake are better off than those far away from the lake, which is in line with a previous study. Geheb et al. (2008) found substantially lower rates of child malnutrition in households within $25 \mathrm{~km}$ of the lake compared to those in the range $25-35 \mathrm{~km}$ from the lake. 
Table 8. OLS Regression on Income measured as log expenditure per adult equivalent.

\begin{tabular}{|c|c|c|c|}
\hline & \multicolumn{2}{|l|}{2008} & \multirow{2}{*}{$\begin{array}{l}1993 \\
\text { Weighted }\end{array}$} \\
\hline & Model 1 & Model 2 & \\
\hline household_count_adultequiv & $-0.350 * * *$ & $-0.326 * * *$ & $-0.162 * * *$ \\
\hline household_count_adultequiv_sq & $0.022 * * *$ & $0.020 * * *$ & $0.006 * * *$ \\
\hline head_age & 0.023 & 0.003 & -0.001 \\
\hline head_gender & -0.055 & -0.070 & -0.074 \\
\hline head_activity_farmwork & \multicolumn{3}{|c|}{ Reference alternative } \\
\hline head_activity_looking_for_work & Dropped & dropped & 0.296 \\
\hline head_activity_fishing & 0.340 & 0.335 & $0.874 * *$ \\
\hline head_activity_paid_employee & 0.168 & 0.184 & $0.275 * * *$ \\
\hline head_activity_self_employed & $0.195 * *$ & $0.217 * * *$ & $0.459 * * *$ \\
\hline head_activity_missing & Dropped & dropped & 0.129 \\
\hline head_educ_none & $-0.451 * * *$ & $-0.466 * * *$ & -0.040 \\
\hline head_educ_primary & \multicolumn{3}{|c|}{ Reference alternative } \\
\hline head_educ_secondary & $0.739 * * *$ & $0.753 * * *$ & $0.425 * * *$ \\
\hline head_educ_postsecondary & $0.800 * * *$ & $0.813 * * *$ & $0.395 *$ \\
\hline head_educ_adult & Dropped & dropped & -0.196 \\
\hline head_educ_other & $-0.323^{*}$ & $-0.289 *$ & dropped \\
\hline head_educ_missing & Dropped & dropped & $0.621 * * *$ \\
\hline Village_lake_10km & $0.157 * *$ & & \\
\hline Village_lake_2km & & $0.190 * *$ & \\
\hline Intercept & $14.11 * * *$ & $14.06 * * *$ & $14.10 * * *$ \\
\hline $\mathrm{N}$ & 502 & 502 & 515 \\
\hline adj. R2 & 0.270 & 0.273 & 0.317 \\
\hline
\end{tabular}

${ }^{\mathrm{a}} 1993$ price variables adjusted for inflation using IFS series 73864ZF CPI urban areas (all families) (IMF 2010) from date of survey to October 2008. ${ }^{*} p<0.10,{ }^{* *} p<0.05,{ }^{* * *} p<0.01$

\section{DISCUSSION AND CONCLUSIONS}

This paper aims at assessing the welfare development in the two Tanzanian regions Mwanza and Mara by the Lake Victoria that experienced a major upsurge in fishing and fisheries export during 1993-2008. Our point of the departure is the theoretical model by Brander and Taylor (1997) that we try to test empirically using two samples of household surveys carried out in 1993 and 2008. The ultimate purpose is to shed light on whether the booming fish industry in Lake 
Victoria during the same period have impacted welfare development in the regions using a micro level perspective.

Our results indicate that average income in 2008 Tsh has increased in both rural and urban areas, with an average expenditure share for food substantially decreasing from 1993 to 2008. Looking at the poorest part of the population we found that the fraction of those below a basic needs level in rural areas were only modestly and non-significantly reduced between 1993 and 2008, which is in line with the general trend from national HBSs in Tanzania carried out during the period. For urban areas we found a substantial reduction in the fraction below basic needs, indicating that the poorest in the urban areas of the two regions have had a better development than in Tanzanian other urban areas on average and at least as good as in Dar es Salaam. Concerning human capital measured as education for the household head we found substantial improvements in educational level and a simple regression model confirms the significant impact of education on household income. We also found that households on average are better off when situated close to the lake. So far, our results indicate that if having an impact of the welfare on the population by the lake, there is more support in our data that the fish boom has had a positive effect rather than the opposite on the well-being of those residing in Mwanza and Mara.

However, the average growth in real income over the period is modest and there is a substantial increase in inequality when comparing the Gini coefficients for the sample in 1993 with the 2008 sample. Hence, growth in real income has primarily accrued to the wealthier part of the population. The very poorest in Mwanza and Mara have had a very limited increase in real income, which questions the existence of a "trickle down" effect from the Nile perch export. As shown in Figure 1, Nile Perch landings have been quite stable in the study period. Despite repeated warnings from biologists, we cannot say for sure that catches will decline in the future, 
which may lead to a reduction in welfare. Moreover, welfare as we measure it in our survey is of course affected by a multitude of factors: education level, changes in capital stock, openness to trade in other sectors etc. Clearly, these effects could dominate an unidentified negative effect from increased export of Nile Perch. Thus, our analysis does not confirm the Brander and Taylor story, and we cannot dismiss that a decline in welfare can eventually occur due to increased harvesting resulting from trade liberalization. Béné et al. (2010) characterize the debate about international fish as two opposing views where advocates promote the view that export and trade liberalization is pro-poor, while critiques claim that fish export imply food insecurity. The same dispute has occurred concerning the Nile perch export oriented fishery in Lake Victoria (Abila, 2003; Abila and Jansen, 1997; Bokea and Ikiara, 2000). Béné et al. (2010) study the issue on a macro perspective using national data for countries in sub-Saharan Africa and their results fail to give support two any of these polarized views. Geheb et al. (2008) have a more micro level approach using health data on occurrence of malnutrition, and strongly reject the claim that there is a direct linear relationship between Nile perch export and the high frequency of malnutrition among population in lake regions of all three countries surrounding the lake. They also stress that exporting food does not imply taking away the food per se, "It is cash and the way this is distributed within households that matters...” (Geheb et al., 2008, p.88), further they found that fishermen unanimously held that factories had been beneficiary for their business and had led to higher prices. Yet, our survey, primarily asking non-fishermen, find that a vast majority hold that the impact of the fish factories and the fish export is primarily negative, leading to increasing fish prices and reduced availability. Brown et al. (2005a) showed the biological interrelationship between dagaa and Nile perch implying that fishing down the Nile perch stock may increase the abundance of dagaa, which in turn implies changing fishing patterns. Mkumbo et al. (2002) confirm recovery of Haplochromis and other prey species as the Nile perch stock has been 
reduced. Dagaa landings increased dramatically from 1993 to 2006 (LVFO, 2012). Brown et al. (2005b) also discuss how changing fishing patterns may have a strong gender effect as females are much more involved in catching and handling dagaa and haplochromis, compared with Nile perch fishing which primarily imply work for males. Geheb et al. (2008) also focus on the gender issue and hold that it is a major reason for the high frequency of malnutrition around the lake, household income have increased but is more unequal within households. Smith et al. (2003) is another study emphasizing the gender aspect, which claim that improving the status of women vis-à-vis men likely improves nutrition of children.

In this study we have quantitatively assessed the welfare development in the Tanzanian Lake Victoria regions, Mwanza and Mara. Our results add to the empirical studies that reject the claim that the dramatic upsurge in Nile perch export has led to food shortage and deteriorating conditions for the local population, a narrative widespread outside the scientific community inter alia due to the documentary "Darwin's Nightmare" (for a critical analysis of the film, see Molony et al., 2007). Still, there is certainly room for improvement. The bargaining power between fishermen and process factories is strongly uneven, a fact reinforced by the open access conditions which also imply suboptimal use of the fish resources. There are unacceptable high numbers of children malnourished around the lake, and in the case of Tanzania figures are higher than average for the whole country. Recommending policies is beyond the scope of this study. Geheb et al. (2008) provide an insightful discussion in favour of improving the status and income of women, while Béné et al. (2010) primarily promote the development of regional trade (Africato-Africa) as a means of improvement. 


\section{References}

Abila, R.O., 2003. Fish trade and food security: are they reconcilable in Lake Victoria? In: FAO, Report of the Expert Consultation on International Fish Trade and Food Security, Casablanca, Morocco, 27-30 January, 2003. FAO Fisheries Report No. 708. Rome, Food and Agricultural Organization, pp. 128-153.

Abila, R.O., Jansen, E.G., 1997. From local to global markets: the fish exporting and fishmeal industries of Lake Victoria - structure, strategies and socio-economic impacts in Kenya. IUCN Eastern Africa Programme. Socio-economics of the Lake Victoria fisheries: Report No. 2. Nairobi, Kenya, The World Conservation Union.

Apollon, 2006. Fish export - causing loss for local population. June 26, Apollon Research Magasin. Oslo: University of Oslo.

Balirwa, J. S., C. A. Chapman, L.J. Chapman, I. G. Cowx, K. Geheb, L. Kaufman, R. H. LoweMcConnell, O. Seehausen, J.H. Wanink, R.L. Welcomme, and F. Witte. 2003. 'Biodiversity and Fishery Sustainability in the Lake Victoria Basin: An Unexpected Marriage?’ BioScience 53(8): 703-716.

Béné, C., R. Lawton and E.H. Allison. 2010. Trade Matters in the Fight Against Poverty: Narratives, Perceptions, and (Lack of) Evidence in the Case of Fish Trade in Africa. World Development 38(7): 933-954.

Bhagwati, J. 2001. Free Trade Today. Princeton: Princeton University Press.

Bokea, C., Ikiara, M., 2000. The macroeconomy of the export fishing industry in Lake Victoria (Kenya). Socio-economics of the Lake Victoria fisheries. Report No. 7, April 2000. The World Conservation Union, Nairobi, Kenya.

Brander, J. And M.S. Taylor. 1997. "International Trade and Open Access Renewable Resources: The Small Open Economy Case” Canadian Journal of Economics 30: 526-52.

Brown, G., B. Berger., \& M. Ikiara. 2005a. 'A Predator-Prey Model with an Application to Lake Victoria Fisheries’. Marine Resource Economics, 20(3):221-48.

Brown, G., B. Berger., \& M. Ikiara. 2005b. 'Different Property Rights Regimes in the Lake Victoria Multiple Species Fishery’. Environment and Development Economics 10(1): 5365.

Bulte, E. and E.B. Barbier. 2005.

Chichilnisky, G. 1994. "North-South Trade and the Global Environment”, American Economic Review 84: 851-874.

CIA The World Factbook. Accessed 2012. www.cia.gov/Deaton, A. 1997. The Analysis of Household Surveys: a microeconometric approach to development policy. The Johns Hopkins University Press: Baltimore.

Deaton, A. 2001. Counting the World's Poor: Problems and Possible Solutions. The World Bank Research Observer 16(2): 125-147.

Dercon, S., and P. Krishnan. 1998. Changes in Poverty in Rural Ethiopia 1989-1995: Measurement, Robustness Tests and Decomposition,” Working Paper, Centre for the Study of African Economies, Oxford University.

Eele, G., J. Semboja, S. Likwelile and S. Ackroyd. 2000. Meeting International Poverty Targets in Tanzania. Development Policy Review, 18: 63-83.

Eggert, H. and R. Lokina. 2010. 'Regulatory Compliance in Lake Victoria Fisheries' Environment and Development Economics 15(2):197-217

Elbers, C., J. Lanjouw and P. Lanjouw. 2003) 'Micro-level Estimation of Poverty and Inequality', Econometrica, 71 (1): 355-64. 
FAO. 2010. Dataset. FishStat Plus-Universal software for fishery statistical time series. http://www.fao.org/fishery

Fischer, C. 2010. Does trade help or hinder the conservation of natural resources?Review of Environmental Economics and Policy

Geheb, K., S. Kalloch, M. Medard, A-T Nyanpendi, C. Lwenya, M. Kyangwa. 2008. Nile perch and the hungry of Lake Victoria: Gender, status and food in an East African fishery. Food Policy 33: 85-98.

Gordon, S.H. 1954. 'The Economic Theory of a Common Property Resource: The Fishery'. Journal of Political Economy, LXII (1): 124-151.

Hentschel, J., J. Lanjouw, P. Lanjouw and J. Poggi. 2000. Combining Census and Survey Data to Trace the Spatial Dimensions of Poverty: A Case Study of Ecuador', World Bank Economic Review, 14: 147-65.

HRDS. 1996. Human Resource Development Survey by The Population and Human Resources Division of the East Africa Department of the World Bank in collaboration with the University of Dar-es-Salaam and the Government of Tanzania's Planning Commission). http://www.worldbank.org/

Jansen, E. G. (1997). Rich fisheries - Poor fisherfolk. Some preliminary observations about the effects of trade and aid in the Lake Victoria fisheries. IUCN report no. 1, September 1997. Nairobi, Kenya: The World Conservation Union (IUCN), 23pp.

IMF. 2010. IFS data base. http://www.imfstatistics.org/imf/about.asp

Kolding, J., van Zwieten, P., Mkumbo, O. , Silsbe, G. and Hecky, R. 2008. Are the Lake Victoria fisheries threatened by exploitation or eutrophication? Towards an ecosystem based approach to management. pp. 309-354 In Bianchi, G. and Skjoldal, H.R. (eds.) The Ecosystem Approach to Fisheries. CAB International, Rome.

Lipsey, R. and K. Lancaster (1956), 'The General Law of Second Best', Review of Economic Studies 24, 11-32.

LVFO. 2004. Regional Status Report on Lake Victoria Frame Surveys for 2000, 2002 and 2004 Unpublished manuscript, LVFO Secretariat, Jinja, Uganda.

LVFO, 2012. http://www.lvfo.org/ Accessed May, 2012.

Minot, N. 2000. Generating Disaggregated Poverty Maps: An Application to Vietnam', World Development, 28 (2): 319-31.

Minot, N. 2007. Are poor, remote areas left behind in agricultural development: the case of Tanzania. Journal of African Economies 17(2): 21-58.

Mkumbo, O.C., C. Ezekiel, Y.L. Budeba, and I.G. Cowx. 2002. “Analysis of Exploitation Patterns for Nile Perch, Lates niloticus, in Lake Victoria.” In Management and Ecology of Lake and Reservoir Fisheries, edited by I.G. Cowx, 84-95. Oxford: Blackwell Science/Fishing News Books.

Molony, T., Richey, L. A., \& Ponte, S. (2007). 'Darwin’s Nightmare’: A critical assessment. Review of African Political Economy, 113, 598-608.

National Bureau of Statistics (Tanzania). 2008. 'Household Budget Survey 2007_Final Report' Dar es Salaam: National Bureau of Statistics Tanzania.

National Bureau of Statistics. Tanzania. 2010. Household Budget Survey. http://www.nbs.go.tz/nada3/index.php/ddibrowser/2 
Njiru, M., Nzungi, P., Getabu, A., Wakwabi, E., Othina, A., Jembe, T. and Wekesa, S. 2007. Are fisheries management, measures in Lake Victoria successful? The case of Nile perch and Nile tilapia fishery. African Journal of Ecology 45, 315-323.

Pitcher, T.J., and A. Brundy. 1995. “Assessment of the Nile Perch Fishery in Lake Victoria.” In The Impact of Species Changes in African Lakes, edited by T.J. Pitcher and P.J.B. Hart. London: Chapman and Hall.

Sarris, A., and P. Tinios. 1995. Consumption and poverty in Tanzania in 1976 and 1991: A comparison using survey data. World Development 23(8): 1401-1419.

Warui, S. W. 2007. Rents and Rents Drain in the Lake Victoria Nile perch Fishery. Final Project. UNU-Fisheries Training Programme.

\footnotetext{
${ }^{i i}$ The 1993 data used in this paper come from a nationally representative survey of 5,000 households in Tanzania. The survey was a joint effort undertaken by the Department of Economics of the University of Dar es Salaam, the Government of Tanzania, and the World Bank, and was funded by the World Bank, the Government of Japan, and the British Overseas Development Agency. The World Bank is not responsible for the estimations reported.

iii The average number of gill nets per vessel increased by $20 \%$ and the share of vessels with an outboard motor increased from $10 \%$ to $20 \%$ from year 2000 to 2006. In addition, landings of the low value dagaa have increased dramatically since 1994. Hence, the reduction in value per unit effort (vpue), expressed as Tsh landed per boat and year is larger than the cpue reduction shown in Figure 2.

${ }^{\text {iv }}$ A recent study, completely at odds with previous biological assessments, holds that the Nile perch stock has not declined despite the increased fishing effort. Instead, the high landings and the steadily increasing fishing effort have been completely off set by an increased biological production in the lake that primarily is driven by eutrophication. Hyper-eutrophication and not overfishing is the major threat to Lake Victoria (Kolding et al, 2008).

vThe HBS results for Dar es Salaam were 28.1/17.6/16.4\% from 91/92, 00/01 and 2007 respectively, indicating a similar magnitude in reduction of fractions below the basic needs level.
} 